\title{
The Effect of Example Non Example Model towards Students' Vocabulary Mastery at the First Grade students of SMAN 4 Mataram.
}

\author{
Tawali \\ University of Mandalika Education, Faculty of Culture, Management and Business \\ tawaliyosi21@gmail.com
}

\begin{abstract}
This research was aimed at finding out the effect of example non example model towards students' vocabulary mastery at the first grade students of SMAN 4 Mataram. This research was an experimental research with quasi experimental and category of this research was non-equivalent control group design. The population of this research was the first grade students of SMAN 4 Mataram consist of 210 students. The instrument that used to collect the data was test consisted of post test. The data was analysis using statistical formula of t-test. The result of data analysis showed that the value of t-test was 4.39 and t-table 2.00. So the value of t-test is higher than t-table in significance level 0.05 and degree of freedom 62-2. It meant that $t$-critical value was significant for this confidence level. So that way, alternative hypothesis $(\mathrm{Ha})$ was accepted and null hypothesis $(\mathrm{Ho})$ was rejected. Therefore, it could be concluded that there was an effect of using example non example to teach vocabulary at the first grade students of SMAN 4 Mataram.
\end{abstract}

Key Words: Snowballing Technique, Vocabulary

\section{INTRODUCTION}

\section{A. Background of the Study}

Vocabulary is one of the components of language that are very important for English communication. If people have lack vocabulary, they will have difficulties to express their feeling and idea to other people. In this case to read and understand the text, they have to mastery vocabulary. It also can avoid people have the trouble to speak and answer some question in spoken and written form. According to Allen (1983: 17) vocabulary is best learned when someone feels that a certain word is needed.The more they master the vocabulary the better they used the language skill such as: speaking, reading, listening and writing because the mastery of vocabulary will very helpful when the students learn foreign language.

In teaching vocabulary is not easy for teachers, many teachers were still having less creativity in teaching English. Usually the teachers just explain the material without any model, so it can make the students bored. Teachers must be able to choose and use multiple model of teaching. As teachers, they must build the interest of students to learn English by using varieties of model. The selection of a model needs to consider the Jurnal Ilmiah Mandala Education material presented, learning objectives, time available, and the number of students as well as matters related in teaching and learning process.

The most important thing is learning English especially in learning vocabulary because without vocabulary the students are difficult to express the idea in language. moreover, vocabulary is fundamental in learning a language. Thus, without vocabulary nothing can be conveyed (Thornbury, 2002: 13).

Based on the writer observation of the students in SMAN 4 Mataram, the researcher found many problems that the students were less in vocabulary. Thestudents usually confused in remembering or mastering vocabulary. On the other hand, the students do not understand when teacher explains the material by using English. Here,the writer founds several problems about students' problem in mastering vocabulary such asdifficultiesin grammatical, difficulties to understanding the meaning of words, difficulties in pronouncing words correctly, the students can not spell the words correctly, and the students can not use and understand the reference well. Moreover, the method of the 
teacher in teaching vocabulary is not suitable to develop the students' vocabulary. They only explain the material to the students. It was cause the students bored in the class.

To overcome the problems of the students, the researcher used example non example model in teaching vocabulary. Example non example one of the strategy could use to teach vocabulary in teaching learning especially in vocabulary. The researcher used example non example model to make the students active and enjoy in the class with their teacher, and didn`t make the students bored in the class and easy to understand or memorize the vocabulary.

Based on the explanation above, the research was conducted research in this school which aimed to find out the effect of example non example model towards students' vocabulary mastery at the first grade of SMAN 4 Mataram

\section{B. Statement of the Problems}

Based on the problem of the study above, the researcher formulated the research question as follow: "Is there any effect of example non example model towards students' vocabulary mastery at the first grade students of SMAN 4 Mataram?',

\section{Purpose of Study}

The purpose of the study in this research is" "To find out the effect of example non example model towards students' vocabulary mastery at the first grade students of SMAN 4 Mataram."

\section{Significant of the Study}

There were two significances of the study which can be categories as and practical as follow:

1. Theoretically

The theoretical significance of this research expected to develop the model in teaching vocabulary anytime needed especially in teaching language for vocabulary, the concept of example non example model may help and support not only for teacher but also for the learner language.

2. Practically

Jurnal Ilmiah Mandala Education a. The students

The result of the study expected to be able to help the students to master vocabulary in learning English vocabulary through example non example model.

b. The teacher

The result of this study expected be able to help the teacher to introduce the concept of example non example model in teaching vocabulary anytime needed in the classroom, this concept may help the students to master the vocabulary in learning language.

\section{E. Scope and Limitation of the study}

The study focused on the effect of example non example model towards students'vocabulary mastery while the object of this study at the first students of SMAN 4 Mataram.

\section{F. Definition of the Key Terms}

In this case, the researcher wanted to explain some terms that used in this study to avoid any possible misunderstanding. The key terms are:

1. Vocabulary

According Bauer, (2001: 8) Vocabulary is about words, where they come from, how they change, how they related to each and how we use them to view the world. Vocabulary in this case is dealing with how words are being used in right manner in order to create a right meaning.

2. Example Non Example

According to Huda (2014: 234), example non-example is a learning strategy that use picture as a medium to deliver learning materials. This strategy is completed with picture, so it can be the way for students can analyze the mean of picture into a brief description of what is in the picture.

\section{REVIEW OF RELATED LITERATURE}

\section{A. Theoretical Review \\ 1. Definition of Vocabulary}

According toHilbert \& kamil, (2005: 3) vocabulary is the knowledge of meaning of 
words.All language have words, language emerges first as words, both historically, and in term of the way each of us learned our first and any subsequent languages. The coining of new words never stop. Nor does the acquisition of words. Even in our first language we are continually learning new words, and learning new meanings for old words.

Vocabulary is a challenge for learners, partly because of the size of the task, and partly because of the variety of vocabulary types to be learned including single words, phrases, collocations, and strategic vocabulary as well as grammatical patterning, idioms, and fixed expressions (McCarten, 2007: 18).

Vocabulary is about words, where they come from, how they change, how they relate to each other and how we use them to view the world (Bauer, 2001: VIII). Furthermore vocabulary could be defined as a dictionary or set of words. This general view is reflected in the lexicographical approach to the traditional way of listing words in a dictionary(Takac, 2008: 13).

Based on explanation above, the researcher can conclude that vocabulary is a collection of words that a person knows, it is an important component ofspeaking ability. Without a sufficient vocabulary, students will not be able to understand the reading, listening, speaking, and writing. Vocabulary gives the effect of all skills, without have vocabulary the students can not master a foreign language. If the students have lack of vocabulary, they will be confused or lack of confidence in communication because of all the skills in the English language dealing with words.

\section{The Kinds of Vocabulary}

Some experts divide vocabulary into two types: active and passive vocabulary. Hiebert (2005:3) stated that vocabulary is the knowledge of meanings of words comes in at least two forms that is receptive and productive vocabulary we use when we write or speak. Meanwhile, the second one refers to the words which the students will recognize when they meet them, but which they will probably not be able to pronounce.

a. Receptive Vocabulary
Receptive Vocabulary is that set of words for which an individual can assign meanings when listening or reading. These are words that are often less well known to students and less frequent in use. Individuals may be able assign some sort of meaning to them, even though they may not know the full subtleties of the distinction. Typically, these are also words that individuals do not use spontaneously. However, when individuals encounter these words, they recognize them, even if imperfectly.

b. Productive Vocabulary

Productive vocabulary is the set of words that an individual can use when writing or speaking. They are words that are well-known, familiar, and used frequently.

\section{The Sources of Vocabulary}

Vocabulary becomes important aspect in teaching learning process, so the students must improve their vocabulary. To improve vocabulary, the students must know where the source of vocabulary comes from. Thus, the student will be easier to learn vocabulary in teaching learning process, (Thornbury, 2002:51). They are:

a. List

Many students quite like learning words from lists. One reason is that it is very economical, large numbers of words can be learned in a relatively short time.

b. Course books

Course book includes in task instruction and grammar explanation. Course book contents of segregated and integrated vocabulary work. Segregated activities typically present or word formation rules, and integrated into skills work typically in vocabulary focus.

c. Vocabulary books

Vocabulary books are as an exercise book for students. Vocabulary book are usually organized, but cover a range of vocabulary skills.

d. The teacher

The teacher is a highly productive. Learners often pick up a lot of incidental 
language from their teachers, especially words and phrases associated with classroom processes, such as let's see, now then, is that clear? Have you finished yet? Besides, the teacher's own stories can also serve as a vehicle for vocabulary input.

e. Other students

Other students in the class are a particularly fertile source of vocabulary input. Learners often pay more attention to what other learners say than they do to either the course book or their teacher.

\section{Assesing of Vocabulary}

Discrete, objective, selective, contextindependent vocabulary test have been an important part of the educational measurement scene for almost the whole of the twentieth century. They have all the virtues of an objective language test and became so well established that for a long time they were almost taken for granted. essay vocabulary items are still very much in use, generally using a more contextualised from in the 1990s, with the target words presented at least in a sentence if not a broader linguistic context. At the same time, the prevailing view in language testing is that discrete vocabulary measures are no longer a valid component of tests designed to assess the learners' overall proficiency in a second language. Vocabulary knowledge is assessed indirectly through the test-takers' performance of integrative tasks that show how well they can draw on all their language resources to use the language for various communicative purposes (Read, 2000: 115).

Nevertheless, researches and languageteaching specialists with a specific interest in vocabulary learning have a continuing need for assesment tools. Much of their work can be classified as focusing on either vocabulary size (breadth) or quality of vocabulary knowledge (depth). Vocabulary size has received more attention because, despite the fact that the tests may seem superficial, they can give a more representative picture of the overall state of the learners' vocabulary than an in-depth probe of a limited number of words. Measures of quality of vocabulary knowledge also have value but for quite specific purposes (Read, 2000: 115).
The construct validation vocabulary can be assessed as something separate from other components of language knowledge, even when individual words are tested in relative isolation. This is consistent with other evidence of the integral part that vocabulary plays in language ability, such as the strong relationship between vocabulary tests and measures of reading comprehension.

Such findings lend support to the view that vocabulary should always be assessed in context. However, as the research on the various members of those cloze family of tests shows, the more we contextualise the assessment of vocabulary, the less clear it may be to what extent it is vocabulary knowledge that is influencing the testtakers' performance (Read, 2000: 115).

Furthermore, all test are constructed subjectively by the test, who decides which areas of language to test, since objective test usually have only one correct answer, they can be scored mechanically. The fact that objective tests can be marked by computer is one important reason for their evident popularity among examining bodies responsible for testing large numbers of candidates. Objective tests need not be confined to any one particular skill or element. In one or two well-known tests in the past, attempts have even been made to measure writing ability by a series of objective test items. However, certain skills and areas of language may be tested far more effectively by one method then by another (Heaton, 1989: 25).

\section{Indicators of Vocabulary}

According to Thornbury (2002: 27) there are some factor who make student difficult in vocabulary:

a. Pronunciation

Research shows that words that are difficult to pronounce are more difficult to learn. Potentially difficult words will typically be those that contain sounds that are unfamiliar to some groups of learners such as regular and lorry for Japanese speakers. Many learners find that words with cluster of consonants, such as strength or crisp or breakfast, are also problematic.

b. Spelling 
Sound spelling mismatches are likely to be the cause of errors, either of pronunciation or of spelling, and can contribute to a words difficulty. While most English spelling is fairly law abiding, there are also some glaring irregularities. Words that contain silent letters are particularly problematic: foreign, listen, climbing, bored, honest, cupboard, muscle, ect.

c. Using word

The latter is the most authentic, but even that task is constrained by a contrived situation in which the test taker, usually in matter of seconds, has to come up with an appropriate sentence, which may or may not indicate that the test taker "knows" the word.

\section{d. Meaning}

When to words overlap raining in meaning, learners are likely to confuse them. Make and do are case in point: you make breakfast and make an appointment, but you do the housework and do a questionnaire. Words with multiple meanings, such as since and still, can also be troublesome for learners. Having learned one meaning of the word, they may be reluctant to accept a second, totally different, meaning. Unfamiliar concepts may make a word difficult to learn. Thus, culture specific items such as word and expressions associated with the game cricket ( a sticky wicket, a hat trick, a good innings) will seem fairly opaque to most learners and are unlikely to be easily learned.

\section{B. Example non Example Model}

1. The Definition of Example non Example Model

according to Huda (2014: 234), Example Non-Example is learning strategy that uses images as medium to deliver learning material. Picture Using this image can make the students are able to analyze then describe it in their own opinion. It means that, this strategy will emphasize students on their analyzing. The picture that is used in this strategy can be showed by LCD, projector, or the simple thing like poster. The picture must look clear although far from the students ${ }^{\text {ee }}$ seat, so the backsides students are able to look at the picture clearly.

\section{The Steps of Using Example Non- Example model}

The steps of applying Example Non Example can be done as follows:

1) Teacher prepares pictures that suit with the purpose of learning.

2) Teacher attaches picture on the board or aired over the LCD.

3) Teacher makes several groups that consist of 2-3 students.

4) Teacher gives instructions and a chance for each group to pay attention or analyze the picture.

5) Noting the result of discussion from picture analysis on the paper.

6) Allowing each group to read out the result of their discussion.

7) Based on the comment or students ${ }^{\text {ee }}$ discussion, teacher explains the material according to the goals of learning.

8) The conclusion

On implementing the example nonexample strategy, the English teacher uses the step which proposed by Huda. Those steps are applied in teaching learning process by English teacher.

3. The Advantages and Disadvantages of Example Non-Example Model

Advantages and Disadvantages of example non example model according to Huda, (2014: 236) are as follow:

1) The Advantages

a) The students more critical in analyzing images.

b) The students know the application of the material in the form of a sample image; and

c) The students are given the opportunity to express their opinion.

2) The Disadvantages

a) Not all learning materials can be presented in the form of images.

b) Sometime the teacher needs lot of time to prepare it. 


\section{Theories of vocabulary}

Vocabulary is one of the language part that the students have to acquire student often face difficulties in speaking, students able to speak if they have any vocabulary in their ability. In this case, example non example model can be solution. There are many vocabulary strategies available, in this research writer using example non example model because can increasing student enjoyment in study vocabulary. In addition the use of all students' sense can make student engage with the written text. By using example non example model in teaching vocabulary can helpful for students to get students' vocabulary mastery.

\section{METHOD}

\section{A. Research Design}

The research of this study designed by quantitative methodor experimental study to answer the statement of the problem stated in cahapter one. Accoding to singh ( 2006: 171 ) experimental study is a plan or strategy of investigation conceived so as to solve the research problem. In this study aimed to find out the effect of example non example toward students vocabulary. The type of experimental method used nonequivalent control group design, with pre test and post test. According to Creswell ( 2013: 295 ) quasi experimental design is a form of experimental research in which individuals are not randomly assigned to group. In conducting this research, the researcher gave pre test and post test to know the students ability in learning vocabulary after giving the treatment. So, the researcher devided the sample into two groups namely experimental and control group. Where, in experimental group treated by using example non example and control group treated by using picture and picture. The design of this research as follows:

\section{B. Table 3.1}

\section{The Scheme of Research Designed}

\begin{tabular}{|c|c|c|c|}
\hline Group & Pre-Test & Treatment & Post-Test \\
\hline $\begin{array}{c}\text { Experimental Group } \\
\left(\mathrm{E}_{1}\right)\end{array}$ & $\mathrm{T} 1$ & $\begin{array}{c}\mathrm{X} \\
\text { (example non } \\
\text { example) }\end{array}$ & $\mathrm{X}_{2}$ \\
\hline $\begin{array}{c}\text { Control Group } \\
\mathrm{C}_{1}\end{array}$ & $\mathrm{~T} 1$ & $\begin{array}{c}- \\
\text { (picture and picture) }\end{array}$ & $\mathrm{Y}_{1}$ \\
\hline
\end{tabular}

E1 = Experimental group

$\mathrm{C} 1=$ Control group

$\mathrm{X}=$ Students teach by example non example

- $\quad=$ Students teach by picture and picture

$\mathrm{X} 2=$ Pre-test for experimental group and control

Y1 = Post-test for control group

\section{Population, Sampling and Sample}

1. Population

Population was a group of individuals who have the same characteristic (Creswell, 2012: 142). Population is also known as well-defined collection of individuals or objects known to have similar characteristic. The population of this research first grades students of SMAN 4 Mataram

\section{Sample}

Sample refers to the part of of the universe which is selected for the purpose of investigation (Kothari, 2004: 158). In finding the sample of this study, the researcher used cluster random sampling technique to select the sample of study then lottery.

\section{B. Research Instrument}

In this research, the writer used the vocabulary test. The test in the form of multiple choice consists of 25 questions, with four options. The vocabulary tests cover with indicator of vocabulary. If the student answer is correct the studentgot 4 score but if the student is incorrect answer they got 0 score. So, the total scored 100 . (See Appendix)

\section{Technique of data collection}

In this study the data collected by using pre- test and post-test.

1. Pre-test

The researcher gave Pre test at the first time before teaching them by using different technique for control group and experimental group to know the basic skill of student in vocabulary.

2. Treatment

Where: 
In this study the researcher touch the experimental group by using example non example, and control group treated by using picture and picture, this treatment will be conducted after giving pre-test to the both groups.

3. Post-test

Post-test is the test that gave to the both group after treating them by different strategy, to know the effect of different treatment in increasing the score of vocabulary test.

\section{Techniques of the Data Analysis}

To analysis data, the researcher applied the statistical analysis that is descriptive statistics and inferential statistics. The descriptive used to know the mean, mode, median and standard deviation, whereas the inferential statistic to know t-test.

\section{Descriptive Statistics}

It is used to display the important features of the data. The most commonly used measure of central tendency were mean, mode, median, and standard deviation.

a. Mean

Mean is the technical term for the average or mean is defined as the sum of all the scores divided by the number of scores. To find out the value of mean the researcher use the formula below:

$$
\mathrm{X}=\frac{\sum f i x i}{\sum f i}
$$

Where:

$$
\begin{array}{ll}
\mathrm{X} & \overline{:} \text { The symbol of mean } \\
\sum & : \text { The symbol for summation } \\
x i & : \text { For any score in the set } \\
f i & : \text { Frequency }
\end{array}
$$

(Sugiyono, 2017: 49)

b. Mode

Mode is defined as the most frequently occurring value in a set of scores based on the value of the currently popular (which is become mode) or the values that often appear. To find out the value of mode the researcher uses the formula below:

Where:

$$
\mathrm{M}_{\mathrm{O}}=\mathrm{b}+\mathrm{p}\left(\frac{\mathrm{b} 1}{b 1+b 2}\right)
$$

b

$\mathrm{p}$

$\mathrm{b}_{1} \quad$ : The frequency of interval containing mode reduced by that of previous interval

$b_{2} \quad$ : The frequency of interval containing mode reduced by that of previous interval

(Sugiyono, 2017: 52)

c. Median

Median is an alternative measure of the central value of a set of scores that has been sorted from the smallest until the largest or otherwise from the smallest to the largest. It is defined very simply as that value which has as many scores above it as below it. The formula is:

$$
\mathrm{Md}=\mathrm{b}+\mathrm{p}\left(\frac{\frac{1}{2} n-F}{f}\right)
$$

Where:

Md : Median score

b : The lower limit of the interval within which the median lies

$\mathrm{p} \quad$ : Interval class

n : Number of the students

F : : The cumulative frequency in all intervals the interval containing the median

$f \quad$ : The frequency of cases within the interval containing the median (Sugiyono, 2017: 53)

d. Standard Deviation

Standard deviation is defined as the square-root of the average of squares of deviations, when such deviations for the values of individual items in a series are obtained from the arithmetic average. To find out the value of standard deviation the researcher uses the formula below:

$$
\mathrm{S}=\sqrt{\frac{\sum \mathrm{fi}(\mathrm{xi}-\bar{x})^{2}}{(\mathrm{n}-1)}}
$$

Where:

$$
\begin{array}{ll}
\mathrm{S} & : \text { Standard deviation } \\
\sum_{\mathrm{fi}} & : \text { The sum of } \\
\mathrm{xi} & : \text { Frequency } \\
\mathrm{n} & \text { : The number of sample }
\end{array}
$$


(Sugiyono, 2016: 58)

2. Inferential statistic is used to decide whether the result confirm the predicted effects of independent variable. In other words, this analysis will draw the conclusion whether the scores between the two groups are significant and the use of Example not example is effective or not.

So, in this step, the researcher will substitute the values of $\mathrm{X}_{1}, \mathrm{X}_{2}, \mathrm{~S}_{1}, \mathrm{~S}_{2}, \mathrm{~N}_{1}, \mathrm{~N}_{2}$ in the computational formula for " $t$ " to identify the significant deviation of two mean score:

$$
t=\frac{\left(\bar{X}_{1-} \bar{X}_{2}\right) \sqrt{\left(N_{1}+N_{2}-2\right) N_{1} \cdot N_{2}}}{\sqrt{\left(N_{1} S_{1^{2}}+N_{2} S_{2^{2}}\right)\left(N_{1}+N_{2}\right)}}
$$

\section{Where:}

$\mathrm{X}_{1}=$ mean score of experimental score

$\mathrm{X}_{2} \quad=$ mean score of control score

$\sum \mathrm{X}_{1}=$ total of experimental students score

$\sum \mathrm{X}_{2}=$ total of control students score

$\mathrm{N} \quad=$ number of students

$\mathrm{S}_{1}{ }^{2} \quad=$ standard Deviation of

Experimental group

$\mathrm{S}_{2}{ }^{2}=$ standard Deviation of

Control Group

After that, consult the result between the results of $\mathrm{t}$-test to $\mathrm{t}$-table. If the result or t-test $>\mathrm{t}$-table, the null hypothesis is rejected. If the results of $t-$ test $<\mathrm{t}$-table than the null hypothesis is accepted (Miller, 2005: 67)

\section{RESEARCH FINDING AND DISCUSSI}

\section{A. Research Finding}

\section{Data Description of Vocabulary}

The chapter of the study presented the result of investigation by applying pretest of experimental group score and posttest of control group score.

Table 4.1

Students' Score of pre-test and post test Experimental Group

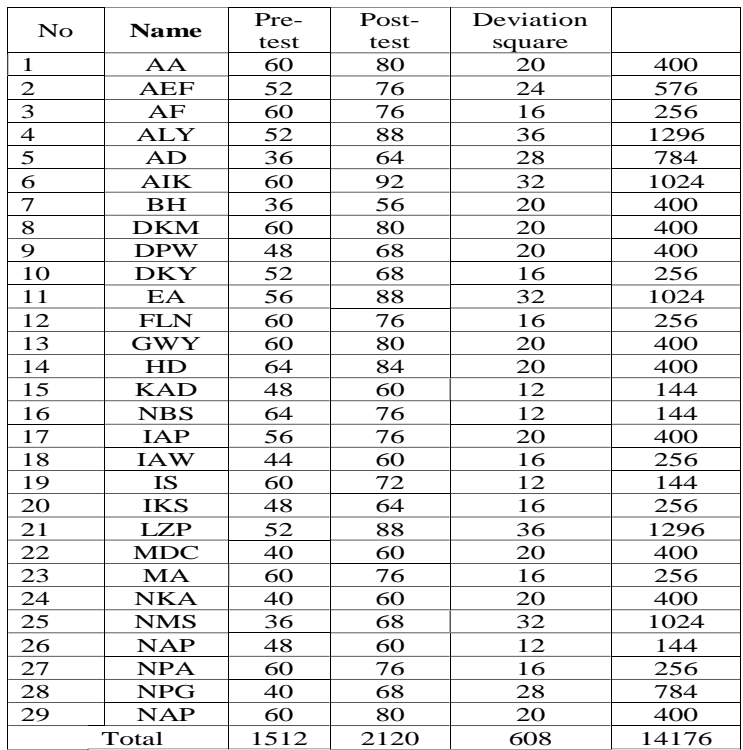

Table 4.1Students' Score of pre-test and post test Control Group

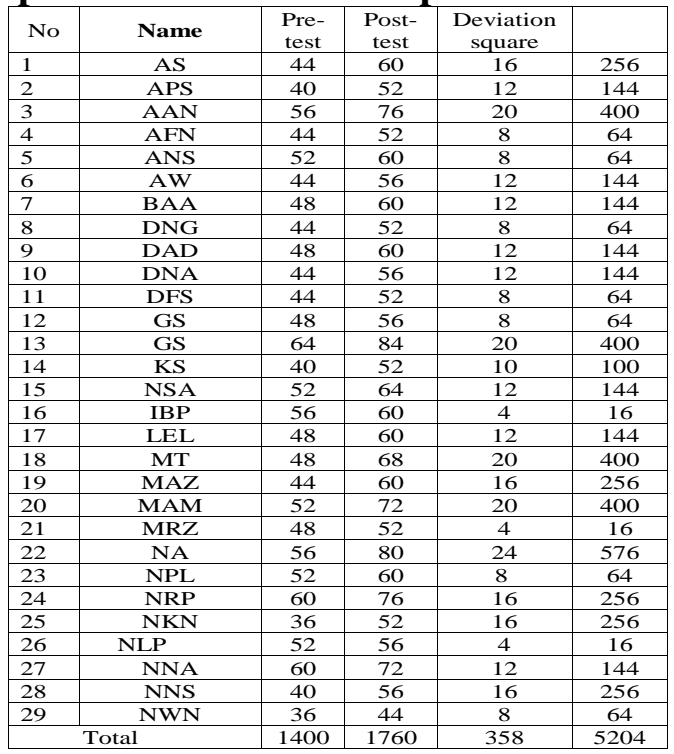

2. The analysis of vocabulary score

\section{Experimental group}

1. Pre-test

a. Mean Score

The mean score of the pre-test was obtained from dividing the sum of the students' score of pre-test with number of the students. Than mean score of the pre test can be seen below:

$$
\begin{aligned}
X & =\frac{\sum f i X i}{n} \\
& =\frac{1497}{29} \\
= & 51,62
\end{aligned}
$$

Based on the result of the computing of the mean score of the pre-test it has been obtained from mean score of the test was 
51,62. After getting the mean score, the researcher started calculate the mode but before that, the researcher classified the frequency distribution.

Table 4.2

Frequency Distribution of Experimental Group

\begin{tabular}{|c|c|c|c|c|c|c|c|c|c}
\hline 60 & 52 & 36 & 52 & 60 & 64 & 60 & 40 & 36 & 40 \\
\hline 52 & 36 & 60 & 56 & 64 & 56 & 48 & 60 & 48 & 60 \\
\hline 60 & 60 & 48 & 60 & 48 & 44 & 52 & 40 & 60 & \multicolumn{1}{|c}{} \\
\cline { 1 - 8 } & & &
\end{tabular}

1. The highest score $=68$

2. The lowest score $=36$

3. Range (r) is $64-36=28$

4. The number of class is $1+(3.3) \log 29=1+$ $(3-3)(1.462)=5.8246$

5. The number of class used $=6$

6 . The class width (interval) $=28: 6=4.6$

7. The class width (interval) used $=5$

Table 4.2

Frequency Distribution of pre-test of Experimental Group

\begin{tabular}{|c|c|c|c|c|c|c|}
\hline No. & $\begin{array}{c}\text { Class } \\
\text { Limits }\end{array}$ & $\begin{array}{c}\text { Class } \\
\text { Boundaries }\end{array}$ & Midpoint & Tally & Frequency & Percentage \\
\hline 1 & $36-40$ & $35.5-40.5$ & 38 & IIIII I & 6 & 20,68 \\
\hline 2 & $41-45$ & $40.5-45.5$ & 43 & I & 1 & 3,44 \\
\hline 3 & $46-50$ & $45.5-50.5$ & 48 & IIII & 4 & 13,74 \\
\hline 4 & $51-55$ & $50.5-55.5$ & 53 & IIII & 4 & 13,74 \\
\hline 5 & $56-60$ & $55.5-60.5$ & 58 & $\begin{array}{c}\text { IIII IIII } \\
\text { II }\end{array}$ & 12 & 41,37 \\
\hline 6 & $61-65$ & $60.5-65.5$ & 63 & II & 2 & 6,89 \\
\hline \multicolumn{5}{|c|}{ Total } & 29 & 100 \\
\hline
\end{tabular}

b. Mode Score

$$
\begin{aligned}
& \mathrm{Mo}=\mathrm{b}+\mathrm{p}\left(\frac{b 1}{b i+b 2}\right) \\
& \mathrm{Mo}=55.5+5\left(\frac{12}{6+1}\right) \\
& \mathrm{Mo}=55.5+3 \\
& \mathrm{Mo}=58.5 \\
& \mathrm{Me}=55.5+1.96 \\
& \mathrm{Me}=56.96
\end{aligned}
$$

c. Median score

$$
\begin{aligned}
& \mathrm{Me}=\mathrm{L}+\mathrm{i}\left(\frac{\frac{n}{2}-c F b}{f w}\right) \\
& \mathrm{Me}=55.5\left(\frac{\frac{29}{2}-9}{14}\right) \\
& \mathrm{Me}=55.5+5\left(\frac{5.5}{14}\right) \\
& \mathrm{Me}=55.5+(0.392) \\
& \text { d. } \text { Standar Deviation }
\end{aligned}
$$

\begin{tabular}{|c|c|c|c|c|c|}
\hline $\begin{array}{c}\text { Class } \\
\text { limit }\end{array}$ & $\begin{array}{c}\text { Frequency } \\
(\mathbf{F i})\end{array}$ & $\begin{array}{c}\text { Mid point } \\
(\mathbf{X i})\end{array}$ & $\mathbf{X i}^{2}$ & $\mathbf{F i} \mathbf{x i}$ & $\mathbf{( F i ~ x i )}$ \\
\hline $36-40$ & 6 & 38 & 1444 & 228 & 51984 \\
\hline $41-45$ & 1 & 43 & 1849 & 43 & 1849 \\
\hline $46-50$ & 4 & 48 & 2304 & 192 & 36864 \\
\hline $51-55$ & 4 & 53 & 2809 & 212 & 44944 \\
\hline $56-60$ & 12 & 58 & 3364 & 696 & 484416 \\
\hline $61-65$ & 2 & 63 & 3969 & 126 & 15876 \\
\hline Total & 29 & 303 & 15739 & 1497 & 635933 \\
\hline
\end{tabular}

$$
\begin{aligned}
S & =\sqrt{\frac{\sum f i x i^{2}-\frac{\left(\sum f i x i \bar{x} i\right)^{2}}{n}}{(n-1)}} \\
& =\sqrt{\frac{635933-\frac{\sum 1497^{2}}{29}}{29-1}} \\
& =\sqrt{\frac{635933-\frac{2241009}{29}}{29-1}} \\
& =\sqrt{\frac{635933-77276}{28}}
\end{aligned}
$$

$$
\begin{aligned}
& =\sqrt{\frac{558657}{28}} \\
& =\sqrt{19952}
\end{aligned}
$$

\section{Graphic 01}

$$
=141.251
$$

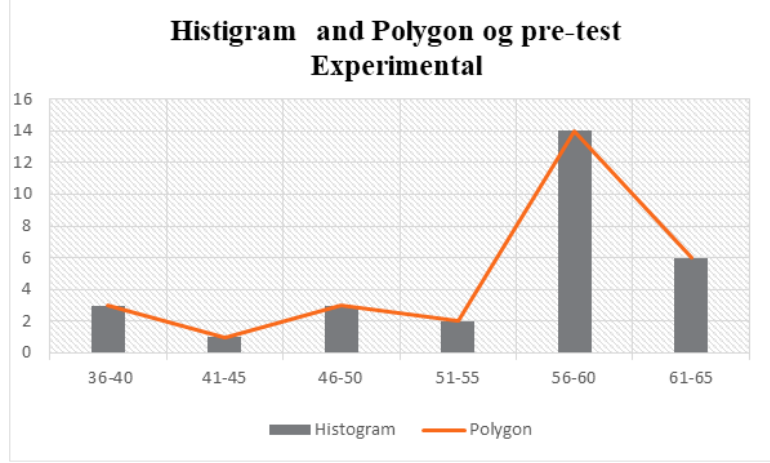

2. Post test

a. Mean score

The mean score of the pre-test was obtained from diving the sum of the students' score of post-test with the number of the students'pre test. The mean score of the posttest can seen bellow:

$$
\begin{aligned}
& X=\frac{\Sigma f i x i}{N} \\
& =\frac{2136.5}{29} \\
& =73.68
\end{aligned}
$$

Based on the result of the ccomputing of the mean score of the post-test it has been obtained the mean score of the test was 73.68. After getting the mean score, the researcher begun calculate the mode but before that, the 
researcher classified the frequeancy distribution.

Table 4.3

Frequency Distribution of Experimental Group

\begin{tabular}{|l|l|l|l|l|l|l|l|l|l|}
\hline 8 & 8 & 5 & 6 & 8 & 7 & 7 & 6 & 6 & 6 \\
0 & 8 & 6 & 8 & 0 & 6 & 2 & 0 & 8 & 8 \\
\hline 7 & 6 & 8 & 8 & 8 & 7 & 6 & 7 & 6 & 8 \\
6 & 4 & 0 & 8 & 4 & 6 & 4 & 6 & 0 & 0 \\
\hline 7 & 9 & 6 & 7 & 6 & 6 & 8 & 6 & 7 & \\
6 & 2 & 8 & 6 & 0 & 0 & 8 & 0 & 6 & \multicolumn{1}{|c}{} \\
\cline { 1 - 4 } & & &
\end{tabular}

1. The highest score $=92$

2. The lowest score $=52$

3. Range ( $r$ ) is $92-56=36$

4. The number of class is $1+$ (3.3) $\log 29=1+(3.3)$ $(1.462)=5.8246$

5 . The number of class used $=$ 6

6. The class width (interval) $=$ $36: 6=6$

7. The class width (interval) used $=6$

Table 4.4

\section{Frequency distribution of post-test of} experimental group

\begin{tabular}{|c|c|c|c|c|c|c|}
\hline No. & $\begin{array}{c}\text { Class } \\
\text { Limits }\end{array}$ & $\begin{array}{c}\text { Class } \\
\text { Boundaries }\end{array}$ & Midpoint & Tally & Frequency & Percentage \\
\hline 1 & $56-61$ & $51.5-57.5$ & 58.5 & IIIII I & 6 & 3,44 \\
\hline 2 & $62-67$ & $57.5-63.5$ & 64.5 & II & 2 & 20,68 \\
\hline 3 & $68-73$ & $63.5-69.5$ & 70.5 & IIIII & 5 & 17,24 \\
\hline 4 & 74-79 & $69.5-75.5$ & 76.5 & IIII II & 7 & 6,89 \\
\hline 5 & $80-85$ & $75.5-81.5$ & 82.5 & IIIII & 5 & 24,13 \\
\hline 6 & $86-92$ & $81.5-88.5$ & 89 & IIII & 4 & 13,97 \\
\hline \multicolumn{5}{|c|}{ TOTAL } & 29 & 100 \\
\hline
\end{tabular}

b. Median Score

$$
\begin{aligned}
& \mathrm{Me}=\mathrm{L}+\mathrm{i}\left(\frac{\frac{n}{2}-c F b}{f w}\right) \\
& \mathrm{Me}=75.5+6\left(\frac{\frac{29}{2}-16}{11}\right) \\
& \mathrm{Me}=75.5+6\left(\frac{-1,5}{11}\right) \\
& \mathrm{Me}=75.5+6(-0.136) \\
& \mathrm{Me}=75.5+5.864 \\
& \mathrm{Me}=81.364
\end{aligned}
$$

c. Mode Score

$$
\begin{aligned}
& \mathrm{M}_{\mathrm{O}}=\mathrm{b}+\mathrm{p}\left(\frac{f i}{f i+f 2}\right) \\
& \mathrm{M}_{\mathrm{O}}=75.5+6\left(\frac{9}{9+9}\right) \mathrm{Mo}=75.5+ \\
& 3 \\
& \mathrm{Mo}=78.5
\end{aligned}
$$

d. Standard Deviation

\begin{tabular}{|c|c|c|c|c|c|}
\hline $\begin{array}{c}\text { Class } \\
\text { limit }\end{array}$ & $\begin{array}{c}\text { Frequency } \\
(\mathbf{F i})\end{array}$ & $\begin{array}{c}\text { Mid point } \\
(\mathbf{X i})\end{array}$ & $\mathbf{X i}^{2}$ & Fi xi & (Fi xi) \\
\hline $56-61$ & 6 & 58.5 & 3422.25 & 351 & 123201 \\
\hline $62-67$ & 2 & 64.5 & 4160.25 & 129 & 16641 \\
\hline $68-73$ & 5 & 70.5 & 4970.25 & 352.5 & 124256.3 \\
\hline $74-79$ & 7 & 76.5 & 5852.25 & 535.5 & 286760.3 \\
\hline $80-85$ & 5 & 82.5 & 6806.25 & 412.5 & 170156.3 \\
\hline $86-92$ & 4 & 89 & 7921 & 356 & 126736 \\
\hline & 29 & 439.5 & 33132.25 & 2136.5 & 847751 \\
\hline
\end{tabular}

$$
\begin{aligned}
S & =\sqrt{\frac{\sum f i x i^{2}-\frac{\left(\sum f i x i\right)^{2}}{n}}{(\mathrm{n}-1)}} \\
& =\sqrt{\frac{847751-\frac{2136.5^{2}}{29}}{29-1}} \\
& =\sqrt{\frac{847751-\frac{4564632.25}{29}}{28}} \\
& =\sqrt{\frac{847751-157401.113}{28}} \\
& =\sqrt{\frac{690349.88}{28}} \\
& =\sqrt{24655.36} \\
& =157.03
\end{aligned}
$$

Graphic 02

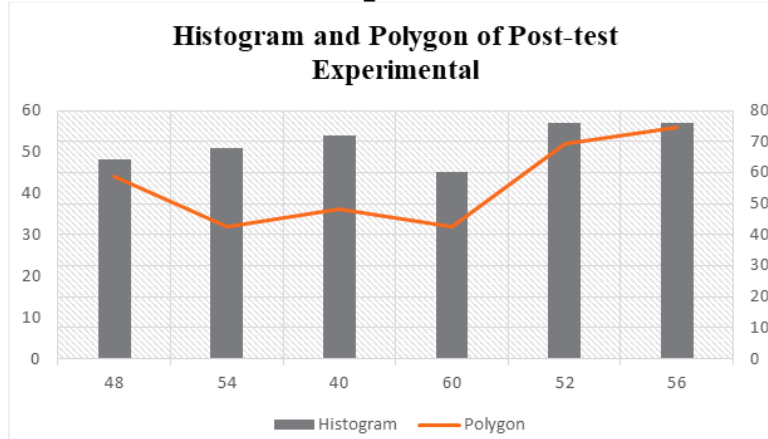

Control group

1. Pre-test

a. Mean score

The mean score of the pre-test was got from dividing the sum of the students' score of pre-test with the number of the students. The mean score of the pre-test can be seen bellow:

$$
\mathrm{X}=\frac{\Sigma f i x i}{N}
$$


$=48,21$

Based on the result of the computing of the mean score of pre-test it has been gotten the mean score of the test was 48,21. After getting the mean score, the researcher continued calculate the mode but before that, the researcher classified the frequency distribution.

Table 4.3

Frequency Distribution of Control Group

\begin{tabular}{|l|l|l|l|l|l|l|l|l|l|}
\hline 4 & 4 & 4 & 4 & 6 & 5 & 4 & 5 & 3 & 4 \\
4 & 4 & 8 & 4 & 4 & 6 & 4 & 6 & 6 & 0 \\
\hline & & & & & & & & & \\
4 & 5 & 4 & 4 & 4 & 4 & 5 & 5 & 5 & 3 \\
0 & 2 & 4 & 4 & 0 & 8 & 2 & 2 & 2 & 6 \\
\hline 5 & 4 & 4 & 4 & 5 & 4 & 4 & 6 & 6 & \\
6 & 4 & 8 & 8 & 2 & 8 & 8 & 0 & 0 &
\end{tabular}

1. The highest score $=64$

2. The lowest score $=36$

3. Renge (r) is $64-36=28$

4. The number of class is $1+(3.3) \log 29$ $=1+(3.3)(1.462)=5.8256$

5. The number of class used $=6$

6. The class width $\quad=28: 6=4.6$

7. The class width (interval) used $=5$

Table 4.4

Frequency Distribution of Pre-test of Control group

\begin{tabular}{|c|c|c|c|c|c|c|}
\hline No. & $\begin{array}{c}\text { Class } \\
\text { Limits }\end{array}$ & $\begin{array}{c}\text { Class } \\
\text { Boundaries }\end{array}$ & Midpoint & Tally & Frequency & Percentage \\
\hline 1 & $36-40$ & $35.5-40.5$ & 38 & IIIII II & 5 & 17.24 \\
\hline 2 & $41-45$ & $40.5-45.5$ & 43 & IIII & 7 & 24.13 \\
\hline 3 & $46-50$ & $45.5-50.5$ & 48 & IIIII I & 6 & 20.68 \\
\hline 4 & $51-55$ & $50.5-55.5$ & 53 & IIII & 5 & 17,24 \\
\hline 5 & $56-60$ & $55.5-60.5$ & 58 & IIIII & 5 & 17,24 \\
\hline C & $61-65$ & $60.5-65.5$ & 63 & I & 1 & 3,44 \\
\hline
\end{tabular}

b. Median score

$$
\begin{aligned}
& \mathrm{Me}=\mathrm{L}+\mathrm{i}\left(\frac{\frac{n}{2}-c F b}{f w}\right) \\
& \mathrm{Me}=75.5+5\left(\frac{\frac{29}{2}-0}{9}\right) \\
& \mathrm{Me}=75.5+5\left(\frac{14-, 5}{9}\right) \\
& \mathrm{Me}=35.5+5(1.61) \\
& \mathrm{Me}=35.5+8.05 \\
& \mathrm{Me}=43.55
\end{aligned}
$$

c. Mode score

$$
\mathrm{M}_{\mathrm{O}}=\mathrm{L}+\mathrm{i}\left(\frac{f i}{f i+f 2}\right)
$$

$$
\begin{aligned}
& \mathrm{M}_{\mathrm{O}}=35.5+5\left(\frac{9}{9+5}\right) \\
& \mathrm{Mo}=35.5+3.21 \\
& \mathrm{Mo}=38.71
\end{aligned}
$$

d. Standard deviation

\begin{tabular}{|c|c|c|c|c|c|}
\hline $\begin{array}{c}\text { Class } \\
\text { limit }\end{array}$ & $\begin{array}{c}\text { Frequency } \\
(\mathbf{F i})\end{array}$ & $\begin{array}{c}\text { Mid point } \\
(\mathbf{X i})\end{array}$ & $\mathbf{X i}^{2}$ & $\mathbf{F i} \mathbf{x i}$ & $(\mathbf{F i} \mathbf{x i})$ \\
\hline $36-40$ & 5 & 38 & 1444 & 190 & 36100 \\
\hline $41-45$ & 7 & 43 & 1849 & 301 & 90601 \\
\hline $46-50$ & 6 & 48 & 2304 & 288 & 82944 \\
\hline $51-55$ & 5 & 53 & 2809 & 266 & 70756 \\
\hline $56-60$ & 5 & 58 & 3364 & 290 & 164836 \\
\hline $61-65$ & 1 & 63 & 3969 & 63 & 85100 \\
\hline Total & 29 & 303 & 15739 & 1398 & 530337 \\
\hline
\end{tabular}

$$
\begin{aligned}
& S=\sqrt{\frac{\sum f i x i^{2}-\frac{\left(\sum f i x i\right)^{2}}{n}}{(n-1)}} \\
&=\sqrt{\frac{530337-\frac{1398^{2}}{29}}{29-1}} \\
&=\sqrt{\frac{530337-\frac{1954404}{29}}{28}} \\
&=\sqrt{\frac{530337-67394}{28}} \\
&=\sqrt{\frac{462943}{28}} \\
&=\sqrt{16534} \\
&=128.58 \\
& \text { Graphic 03 }
\end{aligned}
$$

\section{Histrogam and Polygon of pre-test Control}

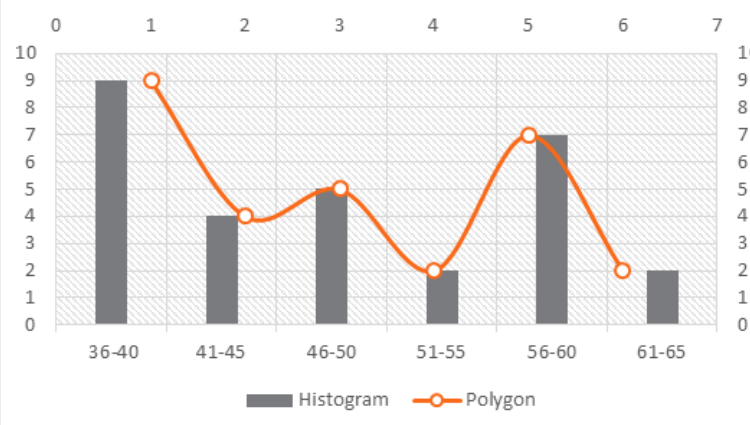

2. Post-test

a. Mean score

The mean score of the pre-test was got from dividing the sum of the students' score of post-test with the number of the students. The mean score of the post-test can be seen below:

$$
\begin{aligned}
X & =\frac{\Sigma f i x i}{N} \\
& =\frac{1777.5}{29}
\end{aligned}
$$




$$
=61.30
$$

Based on the result of the calculation of the mean score of the pre-test it has been obtained the mean score of the test was 61.30. After finding the mean score, the researcher continued calculated the mode but before that, the researcher classified the frequency distribution.

Table 4.3 Frequency Distribution of Control Group

\begin{tabular}{|l|l|l|l|l|l|l|l|l|l|}
\hline 6 & 5 & 6 & 5 & 8 & 6 & 6 & 8 & 5 & 5 \\
0 & 2 & 0 & 6 & 4 & 0 & 0 & 0 & 2 & 6 \\
\hline 5 & 6 & 5 & 4 & 5 & 6 & 7 & 6 & 5 & 4 \\
2 & 0 & 2 & 8 & 2 & 0 & 2 & 0 & 6 & 8 \\
\hline 7 & 5 & 6 & 5 & 6 & 6 & 5 & 7 & 7 & \multirow{2}{*}{} \\
6 & 6 & 0 & 6 & 4 & 8 & 2 & 6 & 2 & \multicolumn{1}{|c}{} \\
\cline { 1 - 5 } & & &
\end{tabular}

1. The highest $=84$

2. The lowest score $=48$

3. Range (r) is $84-48=36$

4. The number of class is $1+(3.3) \log 29=1$

$$
+(3.3)(1.462)=5.8246
$$

5. The number of class used $=6$

6. The class width (interval) $=40: 6=6,6$

7. The class width (interval) used $=6$

Table 4.5

Frequency Distribution of Post-test of

\begin{tabular}{|c|c|c|c|c|c|c|}
\hline No. & $\begin{array}{c}\text { Class } \\
\text { Limits }\end{array}$ & $\begin{array}{c}\text { Class } \\
\text { Boundaries }\end{array}$ & Midpoint & Tally & Frequency & Percentage \\
\hline 1 & $48-53$ & $47.5-53.5$ & 50.5 & $\begin{array}{c}\text { IIIII } \\
\text { III }\end{array}$ & 8 & 27.58 \\
\hline 2 & $54-59$ & $53.5-59.5$ & 56.5 & IIIII & 5 & 17.24 \\
\hline 3 & $60-65$ & $59.5-65.5$ & 62.5 & $\begin{array}{l}\text { IIIII } \\
\text { IIII }\end{array}$ & 9 & 31.03 \\
\hline 4 & $66-71$ & $65.5-71.5$ & 68.5 & I & 1 & 3.44 \\
\hline 5 & $72-77$ & $71.5-77.5$ & 74.5 & IIII & 4 & 13.79 \\
\hline 6 & $78-84$ & $77.5-84.5$ & 81 & II & 2 & 6.89 \\
\hline \multicolumn{5}{|c|}{ TOTAL } & 29 & 100 \\
\hline
\end{tabular}
control group

b. Medain score

$$
\begin{gathered}
\mathrm{Me}=\mathrm{L}+\mathrm{i}\left(\frac{\frac{n}{2}-c F b}{f w}\right) \\
\mathrm{Me}=55.5+6\left(\frac{\frac{29}{2}-12}{11}\right) \\
\mathrm{Me}=55.5+6\left(\frac{2,5}{11}\right) \\
\mathrm{Me}=55.5+(0.22)
\end{gathered}
$$

$\mathrm{Me}=55.5+1.32$

c. Mode score

$\mathrm{M}_{\mathrm{O}}=\mathrm{L}+\mathrm{i}\left(\frac{f i}{f i+f 2}\right)$

Jurnal Ilmiah Mandala Education

$$
\begin{aligned}
& \mathrm{M}_{\mathrm{O}}=55.5+6\left(\frac{2}{4+10}\right) \\
& \mathrm{Mo}=55.5+1.71 \\
& \mathrm{Mo}=57.21
\end{aligned}
$$

d. Standard deviation

\begin{tabular}{|c|c|c|c|c|c|}
\hline $\begin{array}{c}\text { Class } \\
\text { limit }\end{array}$ & $\begin{array}{c}\text { Frequency } \\
(\mathbf{F i})\end{array}$ & $\begin{array}{c}\text { Mid point } \\
(\mathbf{X i})\end{array}$ & $\mathbf{X i}^{2}$ & Fi xi & $(\mathbf{F i} \mathbf{x i})$ \\
\hline $44-49$ & 8 & 50.5 & 2550.25 & 404 & 163216 \\
\hline $50-55$ & 5 & 56.5 & 3192.25 & 282.5 & 79806.3 \\
\hline $56-61$ & 9 & 62.5 & 3906.25 & 562.5 & 316406.3 \\
\hline $62-67$ & 1 & 68.5 & 4692.25 & 68.5 & 4692.25 \\
\hline $68-73$ & 4 & 74.5 & 5550.25 & 298 & 88804 \\
\hline $74-80$ & 2 & 81 & 6561 & 162 & 26244 \\
\hline Total & 29 & 391.5 & 26451.25 & 1777.5 & 679169 \\
\hline
\end{tabular}

$$
\begin{aligned}
& S=\sqrt{\frac{\sum f i x i^{2}-\frac{\left(\sum f i x i\right)^{2}}{n}}{(n-1)}} \\
& =\sqrt{\frac{679169-\frac{1777.5^{2}}{29}}{29-1}}
\end{aligned}
$$

$$
\begin{aligned}
& =\sqrt{\frac{679169-\frac{3159506.25}{29}}{28}} \\
& =\sqrt{\frac{679169-108949}{28}} \\
& =\sqrt{\frac{570220}{28}} \\
& =\sqrt{20365} \\
& =142.705
\end{aligned}
$$

\section{Graphic 04}

Histogram and Polygon of Post-test Control

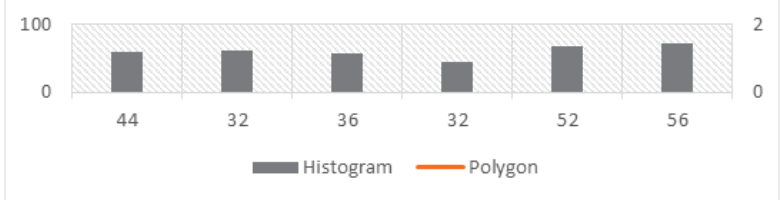

Inferential analysis

It is used to decide whether the result confirmed the predictive effect of the independence of variable. In other word. this analysis drow the conclusion whether the score between the pre-test, and post-test was significance and the using example non-example was effective or not.

For the sake of computation the researcher used formula which is recommended by

Based on the table above that this model example non-example can be used to teach vocabulary in the classroom anytime 
needed particularly English subject in high school.

$$
\begin{aligned}
& t=\frac{\frac{\mathrm{Mx}-M y}{\sqrt{\left(\frac{\sum \times^{2}+\sum \mathrm{Y}^{2}}{\mathrm{~N}_{\mathrm{X}}+\mathrm{N}_{\mathrm{Y}}-2}\right)\left(\frac{1}{\mathrm{~N}_{\mathrm{X}}}+\frac{1}{\mathrm{~N}_{\mathrm{Y}}}\right)}}}{\sqrt{\left(\frac{1429+784}{29+29-2}\right)\left(\frac{1}{29}+\frac{1}{29}\right)}} \\
& t=\frac{8.62}{\sqrt{\left(\frac{2213}{56}\right)\left(\frac{2}{29}\right)}} \\
& t=\frac{8.62}{\sqrt{(39.51)(0.068)}} \\
& t=\frac{8.62}{\sqrt{2.686}}=\frac{8.62}{1.63}=5.28
\end{aligned}
$$

t-test (5.92) $>$ t table $(60.0 .05)(2.00)$

\begin{tabular}{|c|c|c|c|}
\hline \multirow{2}{*}{ t-test } & \multicolumn{3}{|c|}{ t-table } \\
\cline { 2 - 4 } & Df & 0.05 & 0.01 \\
\hline 5.28 & 56 & 2.00 & 2.65 \\
\hline
\end{tabular}

\section{B. Discussion}

Vocabulary is about words where they come from, how they change, how they relate to each other and how we use them to view the world (Laurie Bauer, 2001). Vocabulary is combination words known by a person or a part of a language. The addition of a person's vocabulary is important part, which is obtained from the learning process or the development of a person's ability in a language.

\section{CONCLUSION AND SUGGESTION}

\section{A. Conclusion}

Based on the data analysis and the discussion in the previous chapter, the researcher finally came to a conclusion that the researcher found that t-test score was 3.272 and t-table score was 1.69. It means that alternative hypothesis (Ha) was accepted and the null (Ho) was rejected. The conclusion of example non example is effective on students' vocabulary mastery at the first grade students of SMAN 4 Mataram

\section{B. Suggestion}

Based on the conclusion, the researcher had some suggestion for English teacher, students, and the next researcher:

1. For the Teachers

a. The teacher has to make new innovation in teaching especially for teaching vocabulary so the students do not feel bored.

2. For the Students

a. The students must memorize many vocabularies as good as possible

\section{For Next Researcher}

The researcher hoped that the result of this research is useful study will be useful as the reference for the next researcher that conducting research on similar theme.

\section{BIBLIOGRAPHY}

A,s Homby, 1986Oxford advance learners dictionary of current English. London, oxford university press.

Allen,Virginia French. 1983. Techniques in Teaching Vocabulary. New York: Oxford University Press.

Arikunto,

$\mathrm{S}$. (2010).ProsedurPenelitianSuatuPen dekatanPraktik, Jakarta: RinekaCipta.

Aris, Shoimin. 2006. 68 Pembelajaran Inovatif dalam Kurikulum 2013. Yogyakarta: Ar-Ruzz Media.

Bauer, Laurie. 2001. Vocabulary. New York: Rouletdge.

Creswell, John, W.(2012, 2008, 2005, 2002).Educational

Research.Planning, Conducting, and Evaluating Quantitative and Qualitative Research. FOURTH EDITION.Garamond by Tex Tech. www.Pearsonhighered.Com.

Fauziati, Endang. 2010. Teaching of English as A Foreign Language (TEFL), Surakarta: Era Pustaka Utama. 
Terakreditasi Peringkat 4 (No. SK: 36/E/KPT/2019)

Heaton, J.B. 1989. Writing English Language Testing. New York: Longman.

H.Hiebert, Elfrida \& L.Kamil,Michael. 2005. Teaching \& Learning Vocabulary Bringing Research to Practice. New Jersey: Lawrence Erlbaum Associates, publisher.

Huda, Miftahul. 2014. Model-Model Pengajaran dan Pembelajaran. Yogyakarta: Pustaka Pelajar.

Khotari. 2004. Research Methodology. New Age International Publisher: New Delhi.

Mc. Carten,Jeanne. 2007. Teaching Vocabulary. Lessons from the Corpus.Lessonsfrom the Classroom. USA: Cambridge University Press.

Miller, Stave. 2005. Experimental Design and Statistic. Second Editation. London and New York: Routledge.

Nation, I.S.P. 2000. Learning Vocabulary in Another Language. Available: ir.nmu.org.ua/bitstream/.../1721452a 3f1561f1bd57c2ba30d9ab32.pdf

Read,John. 2000. Assessing Vocabulary. UK: Cambridge University Press.

Sugiyono. 2017. Statistika untuk Penelitian. Bandung. Alfa beta.

Thornburry,Scott. 2002. How to Teach Vocabulary. England: Pearson Education Limited.

Takac,Pacific Vinsja. 2008. Vocabulary Learning Strategies and Foreign Language Acquisition. England: Multilingual Matters. 